\title{
MD INTERVIEW
}

\section{AN INTERVIEW WITH FRANCO MODIGLIANI}

\author{
Interviewed by William A. Barnett \\ Washington University in St. Louis \\ and \\ Robert Solow \\ Massachusetts Institute of Technology
}

November 5-6, 1999

Franco Modigliani's contributions in economics and finance have transformed both fields. Although many other major contributions in those fields have come and gone, Modigliani's contributions seem to grow in importance with time. His famous 1944 article on liquidity preference has not only remained required reading for generations of Keynesian economists but has become part of the vocabulary of all economists. The implications of the life-cycle hypothesis of consumption and saving provided the primary motivation for the incorporation of finite lifetime models into macroeconomics and had a seminal role in the growth in macroeconomics of the overlapping generations approach to modeling of Allais, Samuelson, and Diamond. Modigliani and Miller's work on the cost of capital transformed corporate finance and deeply influenced subsequent research on investment, capital asset pricing, and recent research on derivatives. Modigliani received the Nobel Memorial Prize for Economics in 1985.

In macroeconomic policy, Modigliani has remained influential on two continents. In the United States, he played a central role in the creation of a the Federal Reserve System's large-scale quarterly macroeconometric model, and he frequently participated in the semiannual meetings of academic consultants to the Board of Governors of the Federal Reserve System in Washington, D.C. His visibility in European policy matters is most evident in Italy, where nearly everyone seems to know him as a celebrity, from his frequent appearances in the media. In the rest of Europe, his visibility has been enhanced by his publication, with a group of distinguished European and American economists, of "An Economists' Manifesto on Unemployment in the European Union," which was signed by a number of famous economists and endorsed by several others.

This interview was conducted in two parts on different dates in two different locations, and later unified. The initial interview was conducted by Robert Solow 
at Modigliani's vacation home in Martha's Vineyard. Following the transcription of the tape from that interview, the rest of the interview was conducted by William Barnett in Modigliani's apartment on the top floor of a high-rise building overlooking the Charles River near Harvard University in Cambridge, Massachusetts. Those concluding parts of the interview in Cambridge continued for the two days of November 5-6, 1999 with breaks for lunch and for the excellent espresso coffee prepared by Modigliani in an elaborate machine that would be owned only by someone who takes fine coffee seriously.

Although the impact that Modigliani has had on the economics and finance professions is clear to all members of those professions, only his students can understand the inspiration that he has provided to them. However, that may have been adequately reflected by Robert Shiller at Yale University in correspondence regarding this interview, when he referred to Modigliani as: "my hero."

Keywords: Modigliani, Life-Cycle Saving, Keynes, Corporate Finance

Barnett: In your discussion below with Solow, you mentioned that you were not learning much as a student in Italy and you moved to the United States. Would you tell us more about when it was that you left Italy, and why you did so?

Modigliani: After the Ethiopian war and the fascist intervention in the Spanish Civil War, I began to develop a strong antifascist sentiment and the intent to leave Italy, but the final step was the close alliance of Mussolini with Hitler, which resulted in anti-Semitic laws, which made it impossible to live in Italy in a dignified way. At that time I had already met my future wife, Serena, and we were engaged. Her father had long been antifascist and preparing to leave Italy. When those laws passed, we immediately packed and left Italy for France. We spent 1939 in France, where we made arrangements to leave for the United States. We left in August 1939 for the United States on the very day of the famous pact between Hitler and Stalin, which led to what was the later attack by Germany on Russia. I came to the United States with no prior arrangements with a university. I wanted very much to study economics, and I received a scholarship from the New School for Social Research, thanks in part to the fact that the school had many prominent intellectual antifascists, and one of them, the renowned antifascist refugee, Max Ascoli, helped me to get the scholarship.

Barnett: Franco, I understand that after you had left Italy you returned to Italy to defend your dissertation. Can you tell us whether there were any risks or dangers associated with your return to defend your dissertation?

Modigliani: Yes, it is true that when we left from Rome to Paris, I had finished all of my examinations to get my degree, but I had not yet defended my thesis. In July of 1939, before leaving Paris for the United States, I wanted to have all my records complete, and I decided to go back to Rome to defend my thesis. That operation was not without dangers, because by that time I could have been arrested. I had kept my contacts with antifascist groups in Paris, so there was the possibility of being harassed or being jailed. Fortunately nothing happened. 


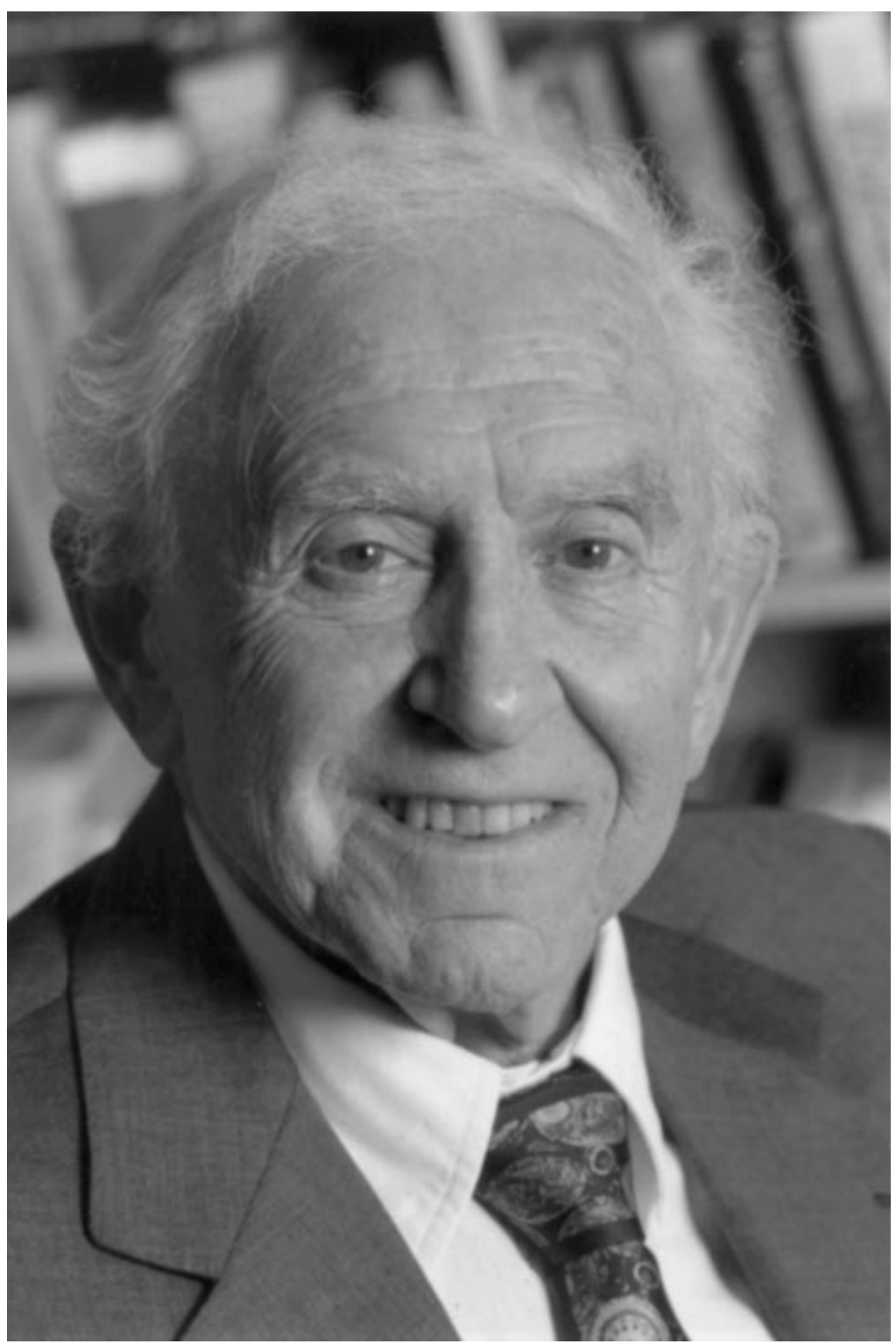

Figure 1. Franco Modigliani (formal portrait photo, date unknown).

My father-in-law was very worried, and we had made arrangements for him to warn us of any impending perils by a code. The code was all about Uncle Ben. If he was not feeling well, we should be ready to go. If he was dead, we should leave instantly. We never needed to use that code, but I felt relieved when I 
was able to complete my thesis, and then late in August we left for the United States.

Barnett: The famous painter and sculptor, Amedeo Modigliani, was born in Livorno, Italy, in 1884 and died in Paris in 1920. Was he related to your family?

Modigliani: There is no known relation.

Solow: Franco, the first thing I want to talk about is your 1944 Econometrica paper, "Liquidity Preference and the Theory of Interest and Money." When you were writing it, you were 25 years old?

Modigliani: Yes, about that. I hadn't studied very much in Italy of any use. There was no useful teaching of economics. What was taught there was something about the corporate state. So all I picked up was at the New School of Social Research in New York with the guidance of Jacob Marschak.

Solow: When was that?

Modigliani: That was 1939 through 1941-1942.

Solow: So your main guide was Jascha Marschak.

Modigliani: Jascha Marschak was my mentor. We studied Keynes and the General Theory in classes with Marschak. I attended two different seminars, but in addition received a lot of advice and support from him. He suggested readings and persuaded me of the importance of mathematical tools, acquired by studying some calculus and understanding thoroughly the great book of the day by R.G.D. Allen, Mathematical Analysis for Economists, and studying some serious statistics (attending Abraham Wald lectures at Columbia); and last but not least he sponsored my participation in a wonderful informal seminar, which included besides Marschak people like Tjalling Koopmans and Oskar Lange. But unfortunately, to my great sorrow, Marschak in 1942 left New York for Chicago. He was replaced by another notable mind, Abba Lerner. I had a lot of discussions with him about Keynes. At that time, Abba Lerner was pushing so-called functional finance.

Solow: Yes, the famous "steering wheel."

Modigliani: Functional finance led me to the 1944 article. In functional finance, only fiscal policy could have an impact on aggregate demand. Therefore, it was an economy that belonged to what I later called the Keynesian case. I tried to argue with Lerner and to have him understand that Keynes did not say that. That was the origin of the 1944 article, trying to put Keynes in perspective.

Solow: Now, with Marschak or Lerner, had you read any of the earlier mathematical models of Keynesian economics, such as Hicks's, of course, or Oscar Lange's articles?

Modigliani: Well, I was familiar with the literature, and of course it had hit me, as is visible in my articles. Hicks's article on Keynes and the classics was a great article, and it was the starting point of my article, except that in Hicks the rigidity of wages was just taken as a datum, and no consideration was given to alternatives. It was just the one system, and fixed forever.

Solow: What he later called "a fix-price model."

Modigliani: Fixed price so that he could deal in nominal terms as though they were real. Money supply is both nominal and real. 


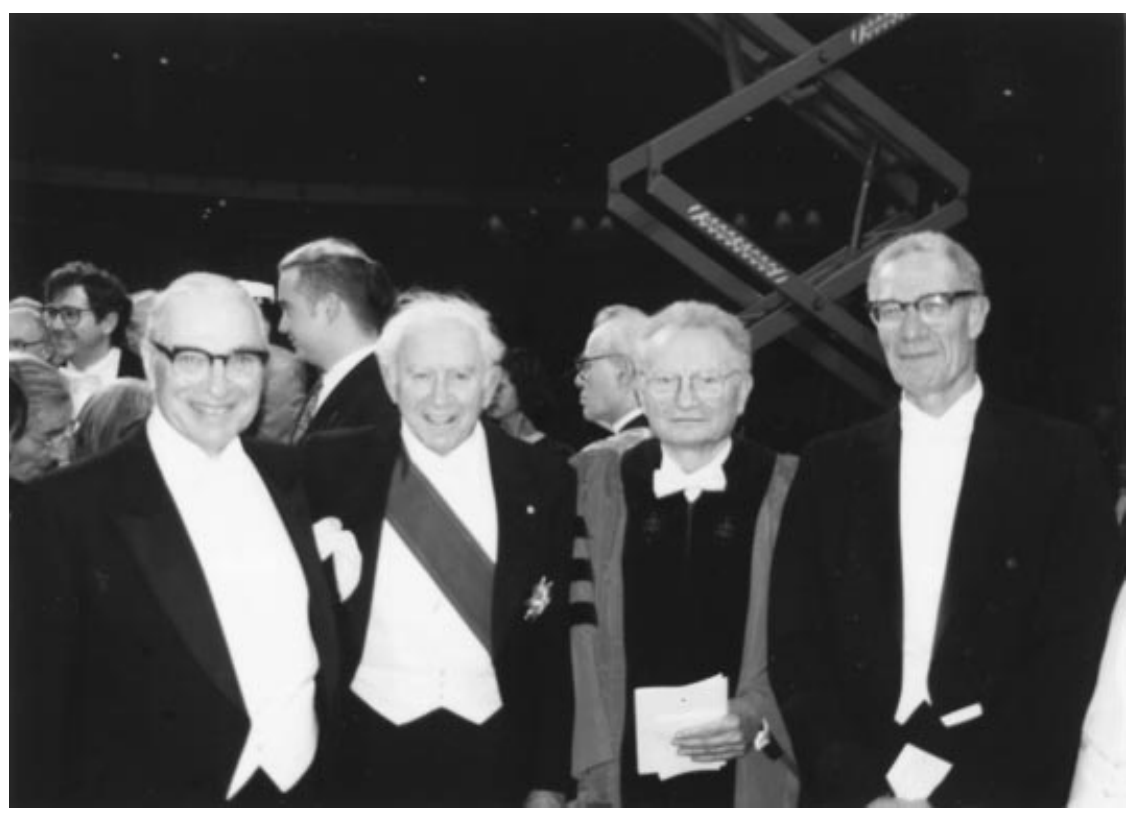

Figure 2. In Stockholm in December 1991 at reunion of the Nobel Prize winners. Left to right are Kenneth Arrow, Franco Modigliani, Paul Samuelson, and Robert Solow.

Barnett: Prior to your arrival at MIT, you were at a number of American universities, including the New School for Social Research, the New Jersey College for Women (now Douglas College), Bard College of Columbia University, the University of Chicago, the University of Illinois, Carnegie Institute of Technology (now Carnegie Mellon University), and Northwestern University. Prior to MIT, what were the most productive periods for you in the United States?

Modigliani: The most productive period was unquestionably the eight years or so (1952 to 1960) spent at Carnegie Tech, with an exceptionally stimulating group of faculty and students, led by two brilliant personalities, the dean, G. L. Bach, and Herbert Simon, working on the exciting task of redesigning the curriculum of modern business schools, and writing exciting papers, some of which were to be cited many years later in the Nobel award: the papers on the life-cycle hypothesis and the Modigliani and Miller papers.

Barnett: I've heard that while you were teaching at the New School, you had an offer from the Economics Department at Harvard University, which at that time was by far the best economics department in the United States. But to the surprise of the faculty, you turned down the offer. Why did you do that?

Modigliani: Because the head of the department, Professor Burbank, whom I later found out had a reputation of being xenophobic and anti-Semitic, worked very hard and successfully to persuade me to turn down the offer, which the faculty had instructed him to make me. He explained that I could not possibly hold up 
against the competition of bright young people like Alexander, Duesenberry, and Goodwin. "Be satisfied with being a big fish in a small pond." Actually it did not take me too long to be persuaded. Then, after my meeting with Burbank, I had scheduled a lunch with Schumpeter, Haberler, and Leontief, who had expected to congratulate me on joining them. But they literally gave me hell for letting Burbank push me over. Nevertheless, in reality I have never regretted my decision. Harvard's pay at that time was pretty miserable, and my career progressed much faster than it would have, if I had accepted the offer.

Barnett: I understand that the great football player Red Grange (the Galloping Ghost) had something to do with your decision to leave the University of Illinois. What happened at the University of Illinois that caused you to leave?

Modigliani: In short it was the "Bowen Wars," as the episode came to be known in the profession. The president of the university brought in a new wonderful dean, Howard H. Bowen, to head the College of Commerce, which included the Department of Economics. But the old and incompetent faculty could not stand the fact that Bowen brought in some first-rate people like Leo Hurwicz, Margaret Reid, and Dorothy Brady. The old faculty was able to force Bowen out, as part of the witch hunt that was going on under the leadership of the infamous Senator Joseph McCarthy. The leader of the McCarthyite wing of the elected trustees was the famous Red Grange. I then quit in disgust with a blast that in the local press is still remembered: "There is finally peace in the College of Commerce, but it is the peace of death." My departure was greeted with joy by the old staff, proportional to their incompetence. But 40 years later, the university saw fit to give me an honorary degree!

Solow: Well, how do you look at the 1944 paper now? Would you change it drastically if you were rewriting it?

Modigliani: Yes! Not really in content, but in presentation. That is what I have been doing in my autobiography. I am revising that paper completely and starting from an approach which I think is much more useful. I am starting from the notion that both the classics and Keynes take their departure from the classical demand for money model, which is one of the oldest and best-established paradigms in economics. The demand for money is proportional to the value of transactions, which at any point can be approximated as proportional to nominal income (real income multiplied by the price level). The nominal money supply is exogenous. Therefore, the money market must reach an equilibrium through changes in nominal income. Nominal income is the variable that clears the money market.

Where then is the difference between classical and Keynesian economics? Simple: The classics assumed that wages were highly flexible and output fixed by full employment (clearing of the labor market). Thus the quantity of money had no effect on output but merely determined the price level, which was proportional to the nominal money supply (the quantity theory of money). On the other hand, Keynes relied on the realistic assumption that wages are rigid (downward). That is, they do not promptly decline in response to an excess supply of labor. Workers do not slash their nominal wage demands, and firms do not slash their wage offers, when unemployment exceeds the frictional level. What, then, clears the money 
market? Again, it is a decline in nominal income. But since prices are basically fixed, the decline must occur in real income and particularly in employment. When there is insufficient nominal money supply to satisfy the full employment demand for money, the market is cleared through a decline in output and employment. As Keynes said, the fundamental issue is that prices are not flexible.

Solow: Not instantly flexible.

Modigliani: That's right. They may very slowly respond, but a very slow adjustment of the real money supply can't produce the expansion of the real money supply needed to produce a rapid reestablishment of equilibrium. What, then, reestablishes equilibrium? Since wages and prices are fixed, the decline in nominal income can only occur through a decline in real income and employment. There will be a unique level of real income that clears the money market, making the money demand equal to the money supply.

Solow: No mention of the interest rate?

Modigliani: The interest rate comes next, as a link in the equilibrating mechanism. In fact, Keynes' unique achievement consisted not only in showing that unemployment is the variable that clears the money market; he also elaborated the mechanism by which an excess demand for money causes a decline of output and thus in the demand for money, until the demand matches the given nominal money supply. In the process of developing this mechanism, unknown to the classics, he created a new branch of economics: macroeconomics.

Macroeconomics, or the mechanisms through which money supply determines output (employment), stands on four basic pillars, with which, by now, most economists are familiar: (1) liquidity preference, (2) the investment function, (3) the consumption or saving function, and (4) the equality of saving and investment (properly generalized for the role of government and the rest of the world).

Liquidity preference is not just the fact that the demand for money depends on the interest rate; it brings to light the profound error of classical monetary theory in assuming that the price of money is its purchasing power over commodities (baskets per dollar) and that, therefore, a shortage of money must result in a prompt rise in its purchasing power (a fall in the price level). In reality, of course, money has many prices, one in terms of every commodity or instrument for which it can be exchanged. Among these instruments, by far the most important one is "money in the future," and its price is money tomorrow per unit of money today, which is simply $(1+r)$, where $r$ is the relevant interest rate.

Furthermore, experience shows that financial markets are very responsive to market conditions: Interest rates (especially in the short run) are highly flexible. So, if money demand is short of supply, the prompt reaction is not to liquidate the warehouse or skimp on dinner, forcing down commodity prices, but a liquidation in the portfolio of claims to future money (or a rise in borrowing spot for future money), leading to a rise in the terms of trade between money today and tomorrow - that is, a rise in interest rates. And this starts the chain leading to lower output through a fall in investment, a fall in saving, and thus in income and employment. It is this fall, together with the rise in interest rates, that reduces the demand for money till it matches the supply. 
Solow: Yes, so the interest rate is a key price.

Modigliani: Actually it's one plus the interest rate. If you are short of money, and the system does not have enough money, the first thing it attempts is to get more spot money by either liquidating assets or by borrowing, which is borrowing money today against money tomorrow. Interest rates rise, reducing investment, and then comes the great equation: investment equals savings — an identity that is so far from the classical view that in the beginning they would not even believe it.

Solow: Right.

Modigliani: And income then adjusts so that the demand for money is finally equated to its supply. This will result in both a higher interest rate and a lower income. The two together will serve to equate the money demanded with the given supplied. And how much must interest rates rise or income decline? That depends upon the parameters of the system (demand elasticities).

Solow: But exactly! And Keynes's fundamental contribution then was to say that it's not the interest rate and the price level, but interest and real output.

Modigliani: Yes, precisely. I think this is the way to look at it. It is the output that adjusts demand and supply.

Solow: What you just described is maybe a different way of telling a story and saying what's important, but it's not fundamentally different from what's in the 1944 paper or in the ISLM apparatus.

Modigliani: Absolutely. But I suggest that to think of unemployment not as a transitory disease, but as a variable that clears the money market, is a useful and significant innovation. Unemployment is an equilibrating mechanism. It seems like a dysfunction, since we think that full employment is what an economy should produce. But unemployment is a systematic feature of an economy relying on money to carry out transactions. To avoid unemployment, it takes continuous care by either setting the right money supply or fixing the right interest rate. There is no other way to get full employment. There is nothing automatic about it.

Barnett: Some work on monetary policy has emphasized the possibility that the monetary transmission mechanism works through a credit channel. The implication of this research is that monetary policy may affect consumer and business spending, because it affects the quantity of credit available to agents, rather than the interest rate. This work is often motivated by the observation that the interest elasticity of spending is too low to explain the large impact monetary policy appears to have on real economic activity. Do you think there is an important credit channel for monetary policy?

Modigliani: My attitude toward this question, about which I have done much thinking and some writing, is that in the end it is an empirical question, not an a priori question. It is entirely credible that monetary policy may work, in part, through changing the volume of credit supplied by banks in the form of commercial loans, as well as its cost. That way it may have the same effects as acting through market interest rates, but without necessarily producing large movements in interest rates. I think that future research will help in sorting this out. But the answer 
will not be perpetual, since the answer depends upon the structure of financial intermediaries and the laws regulating them.

Solow: Now one of the questions I've wanted to ask you, which I think you've already now answered, is what does it mean to be a Keynesian today? But I take it that what you just said is the essence of Keynesian economics, and by that definition you would describe yourself as a Keynesian.

Modigliani: Absolutely. I consider myself a Keynesian. Now as I think it over in this light, I consider Keynesian economics to be a great revolution, having a really tremendous impact, with tremendously novel ideas. Again I consider myself a Keynesian in the very fundamental sense that I know the system does not automatically tend to full employment without appropriate policies. Price flexibility will not produce full employment, and therefore unemployment is always due to an insufficiency of real money. But it must be recognized that there are certain circumstances under which the Central Bank may not be able to produce the right real money supply. For instance, the case of Italy was interesting. Unemployment there was due to the fact that real wages were too high, in the sense that they resulted in substantially negative net exports at full employment. Under those circumstances, if the Central Bank expanded the money supply to create more aggregate demand and employment, the balance of trade would run into nonfinancable deficits, and the Central Bank would be forced to contract. So, you're not always able to increase the real money supply. But that's not the case in Europe, where the money supply could be easily increased and the unemployment is largely due to insufficient real money supply.

Solow: You know I rather agree with you about that.

Modigliani: Interest rates are too high. There is not enough real money being supplied. This is not being understood. Keynes is not being understood. That's the main source of European unemployment. Some improvements in the labor market, such as more wage flexibility, could help, but would not get very far without a significant rise in aggregate demand (which at present would not significantly increase the danger of inflation).

Solow: Right, but you cannot get European central bankers to see that.

Modigliani: In Europe they accept the view that long-lasting unemployment contributes to the current high level because it reduces search by the unemployed, causing long-term unemployment. No, sir. That's a consequence of the too restrictive policy.

Barnett: You have argued that stock market bubbles sometimes are produced by misinterpreting capital gains as a maintainable component of current returns (a permanent addition to current profits). Do you believe that that phenomenon is going on now, or do you believe that current stock market valuations are consistent with the fundamentals?

Modigliani: I am very much interested and concerned about bubbles, and I believe that bubbles do exist. They are one of the sources of malfunctioning of the market mechanism. The essence of these bubbles is that indeed capital gains get confused with profits, and this results in the stock becoming more attractive, so 
people bid up the price, which produces more capital gains, and so on. I believe that indeed the stock market in the United States is in the grips of a serious bubble. I think the overvaluation of stocks is probably on the order of $25 \%$ or so, but, by the nature of the process, it is not possible to predict just when the whole thing will collapse. In my view, there will be a collapse because if there is a marked overvaluation, as I hold, it cannot disappear slowly.

Barnett: How does your research help us understand what has occurred over the past few years in the volatile economies of East Asia?

Modigliani: My view is that what has happened in East Asia is very much in the nature of a bubble, where expected high returns have attracted capital. The attraction of capital has held up exchange rates, permitting large deficits in the balance of trade; the influx of capital has supported the exchange rate making capital investment more attractive. So, you have a spiral until people realize that those returns are really not maintainable. I think it is important for the future of the international situation to set up systems under which bubbles cannot develop or are hard to develop, such as requiring reserves against short-term capital movements.

Solow: Now, I want to ask what's your current belief about wage behavior? How would you today model the behavior of nominal or real wages?

Modigliani: This, I think, is one of the fundamental issues that we face today, because in my model the wage and the price level are exogenous. Why is the price level exogenous? Because prices fundamentally depend upon wages, and wages are not flexible. Wages are certainly not responding mechanically to unemployment. So what do we do about wages? Well, I do think that some of this rigidity of wages is historical. It's very likely that in the nineteenth century the situation was different. In that century there was a greater role for competitive industries such as agriculture. In any event, the wage is the fundamental component of the price level. What's going to determine wages? Well, we've come to a difficult period, mostly since unions in Europe have been very powerful. They've become unreasonable and pushed for higher and higher wages, nominal wages. But my view is that in the long run we'll have to reach the point at which the wage, the nominal wage, is negotiated in a general simultaneous settlement of wages and prices. Now that's what's happened in Italy.

Solow: Say some more about that.

Modigliani: What saved Italy from the tremendously disastrous situation that existed just before devaluation was the fact that workers agreed to fix nominal wages for three years together with a price program, so that real as well as nominal wages were set. To me, that is the future because I do not know what else to say about the price picture.

Solow: What you're saying is that Keynes's remark that labor cannot determine the real wage may turn out to be false because institutions change and permit bargaining over the real wage.

Modigliani: That's right. Yes, yes.

Solow: What's your current feeling about NAIRU, the nonaccelerating-inflation rate of unemployment? 


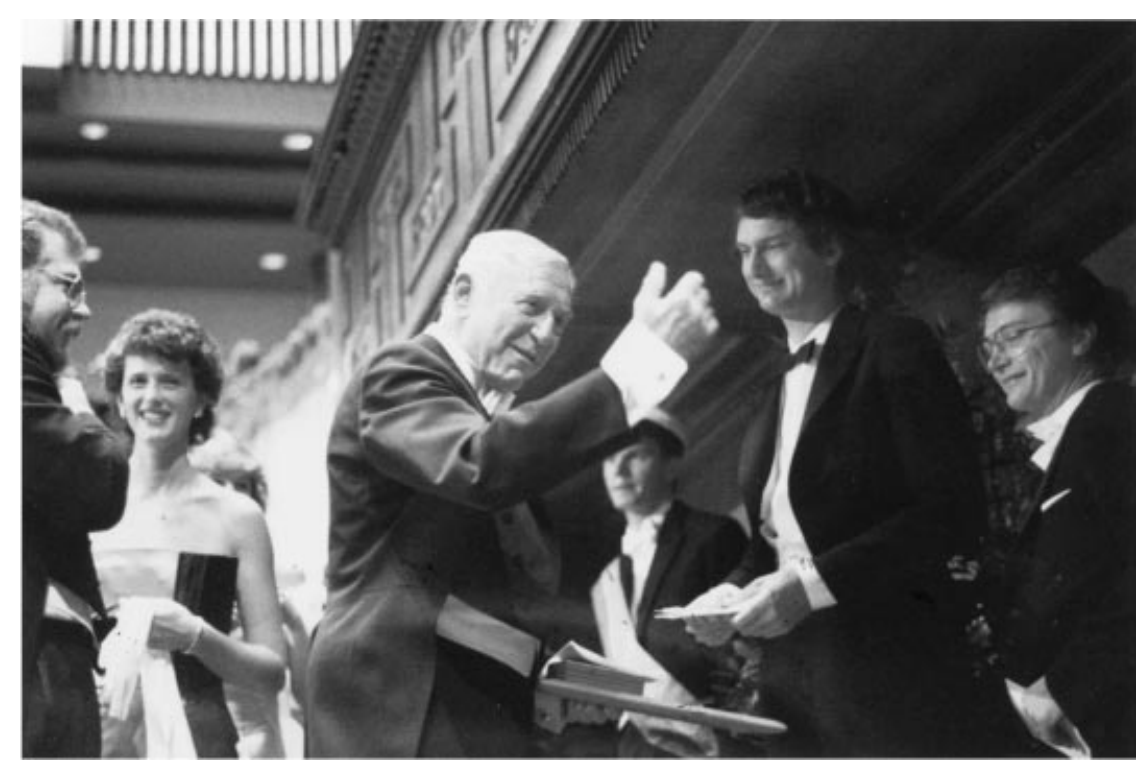

Figure 3. In Stockholm in 1985 after receiving the Nobel Prize.

Modigliani: I think it is true that if unemployment gets too low, then you will have accelerating inflation, not just higher inflation but higher rate of change of inflation. But I do not believe that if unemployment gets very high, you'll ever get to falling nominal wages. You may get very low acceleration of wages, or you may get to the point at which wages don't move. But I don't believe that high unemployment will give us negative wage changes.

Solow: We might even get falling wages for a while, but you would surely not get accelerating reductions in wages. No believer in the NAIRU ever wants to speak about that side of the equation.

Modigliani: That's right. So I think that these views are consistent, in the sense that left alone there may be a tendency for the system to be always in inflation. The Central Bank can pursue full employment policy without simultaneously being concerned that it must keep the inflation rate at zero. What I regard as a real tragedy today is the fact that all of a sudden the European banks and many other banks have shifted to the single-minded target of price stability. I think that is one of the sources of the European tragedy, in contrast with the shining performance of the United States. No concern whatever about employment.

Solow: Well, they argue that there is nothing they can do about it, but you and I think that's fundamentally wrong and simply a way of avoiding responsibility.

Modigliani: Exactly. And on the contrary, I think they should say the priority target should be "first unemployment," though price stability is also very important. There are situations in which indeed you may either have to accommodate inflation or stop it at the cost of temporary unemployment. I think then I would accept 
unemployment as a temporary state to stop an inflationary spiral. But to say that price stability is the only target, I think is wrong.

Solow: So, you don't believe that the NAIRU in France is $13 \%$ today?

Modigliani: Absolutely not, absolutely not. Nor do I believe that here in this country it is as low as $4 \%$. I have great doubts about the stability of NAIRU but even more about the appropriate way to estimate it.

Barnett: While I was an undergraduate student at MIT, I was permitted to take your graduate course in corporate finance. I shared with the graduate students in the class the view that the Modigliani-Miller work on the cost of capital was dramatically raising the level of sophistication of the field of corporate finance. What motivated you to enter that area of research, and what earlier research inspired you?

Modigliani: Ever since my 1944 article on Keynes, I have become interested in empirical tests of the Keynesian structure. As everybody knows, one of the key components of that structure is the investment function, which explains investment in terms of the interest rate, seen as the cost of capital, the cost of funds invested. I was then under the influence of the views of the corporate finance specialists that the cost of funds depended upon the way in which the firm was financed. If you issued stock, then the cost of that would be the return on equity, which might be $10 \%$, but if you used bonds, the cost would be their interest rate, which might be only $5 \%$. That sort of answer didn't seem to me to be very convincing. In the end, what was the cost of capital: $5 \%$ or $10 \%$ ? To an economist it could not be rational to say that the required return was $5 \%$ if you chose to finance the project by debt and $10 \%$ if you chose equity. After listening to a paper by David Durand suggesting (and then rejecting) the so-called "entity theory" of valuation, I gradually became convinced of the hypothesis that market value should be independent of the structure of financing, and was able to sketch out a proof of the possibility of arbitraging differences in valuation that are due only to differences in the liability structure. This result later became part of the proof of the Modigliani-Miller theorem. In essence, the market value of liabilities could not depend on its structure, because the investor could readily reproduce any leverage structure through personal lending or borrowing (as long as there was no tax impediment). As a consequence, there was no difference between the use of equity and debt funds. Even though debt had a lower apparent cost, it increased the required return on equity, and the weighted average of the two would be unaffected by the composition. I unveiled my proof in a class in which Miller happened to be an auditor. He was convinced instantly and decided to join me in the crusade to bring the truth to the Heathens.

The theorem, which by now is well known, was proven very laboriously in about 30 pages. The reason for the laboriousness was in part because the theorem was so much against the grain of the teachings of corporate finance- the art and science of designing the "optimal capital structure." We were threatening to take the bread away, and so, we felt that we had to give a "laborious" proof to persuade them. Unfortunately, the price was paid by generations of students that had to read the paper; I have met many MBA students that remember that paper as a torture, the 
most difficult reading in the course. It's too bad because, nowadays, the theorem seems to me to be so obvious that I wonder whether it deserves two Nobel Prizes. All that it really says is that (with well-working markets, rational-return-maximizing behavior for any given risk, and no distorting taxes) the value of a firm-its market capitalization of all liabilities_-must be the value of its assets. The composition of the claims can change (equity, debt, preferred, convertible preferred, derivatives, and what not), but the aggregate value of the claims cannot change. It is the value of the assets. Of course, it is true that this conclusion implies that the way that you finance investment is immaterial. It follows that in estimating the required return, the cost of capital, we do not have to bother with the details of the composition of the financing. In that sense, Jorgenson is right.

In later years, the Modigliani-Miller theorem has provided the foundation for the work on derivatives, such as options. All of that work assumes that the underlying value of the firm is independent of its current liability structure. But let me remind you of the assumptions needed to establish the theorem and, in particular, the assumption of no distorting effects of taxation on the net-of-tax amount received by an individual from one dollar of before-interest corporate earnings. If there are such effects, then the situation is more complicated, and in fact in this area there is a disagreement between Miller and me. I believe that taxes can introduce a differential advantage between different kinds of instruments, while Miller thinks not. But I should add that even though, in principle, taxation could affect the comparative advantage of different instruments, Miller and I agree that, with the current system of taxation, the differences are unlikely to be appreciable.

Solow: Now I want to make room here for you to make a brief comment about real business-cycle theory. If you look at macroeconomic theory today, what has replaced the Keynesian economics that you and I both accept is, in the minds of young people, real business-cycle theory.

Modigliani: I have no difficulty in believing that business cycles can exist in the real economy. You don't need money, and I myself built models of that kind, when it was fashionable. There was Hicks's article on the business cycle, and then Sidney Alexander had a very interesting article on the introduction of a bound that can permit you to get a cycle without money. But I think that has little to do with Keynesian unemployment. In the thirties, for instance, there was a tremendous depression that I think was caused by an insufficiency of real money. That was a horrible error made by the Federal Reserve, a point on which Milton Friedman and I agree. There was a serious shortage of real money and irresponsible behavior in letting the money supply shrink. I think that unemployment is mostly due to the rigidity of wages and to the shifting conditions. Therefore, there is the need for adjustment by the Central Bank, and the adjustment must be fast enough.

Solow: What's distinctive about real business-cycle theory is not just that it says that the monetary mechanism has nothing to do with cycles, but that business cycles, as we observe them, are optimal reactions of the economy to unexpected shocks to technology and tastes and things like that. 
Modigliani: Yes, yes. Well, of course, much of this goes back to rational expectations, and my attitude toward rational expectations is that it is a wonderful theory. It is indeed the crowning of the classical theory. The classical theory spoke of optimal response to expectations. Lucas and company add optimal formation of expectations. From that point of view, I am satisfied that that is what economic theory would say; and I am proud because I contributed an important concept, which is, I think, at the essence of rational expectations, namely, the existence of expectations that map into themselves.

Solow: Self-validating.

Modigliani: Self-validating. No, not "self-validating"_ “internally consistent."

Solow: That's what I meant by self-validating. There is one set of expectations that is self-validating, not that every set is self-validating.

Modigliani: That's right, because usually self-validating means that it happens because you expect it. This is not the case. In addition, I believe that it is not a description of the world. I don't believe that the world is behaving rationally in that extreme sense, and there are many circumstances under which the model will not apply. In particular, I do not believe that that model justifies the conclusion that anything the government does is bad.

Solow: It adds variance and the mean is already right, so discretionary policy is bad.

Modigliani: It creates noise, so therefore whatever government does is bad. Wage rigidity to me is a perfect example contradicting the above conclusion. Nor can you dispose of wage rigidity with the hypothesis of staggered contract. If that contract is rational, then wages are rigid and one better take this into account in theory and policy; or the staggered contract is not rational and in a Chicago world, it should have long ago disappeared.

Barnett: Robert Barro, who I understood was a student in some of your classes, advocates a version of Ricardian equivalence that appears to be analogous in governmental finance to the Modigliani-Miller theorem in corporate finance and in some ways to your life-cycle theory of savings with bequests. In fact, he sometimes speaks of one of your classes at MIT that he attended in 1969 as being relevant to his views. But I understand that you do not agree with Barro's views of government finance. Why is that?

Modigliani: Barro's Ricardian equivalence theorem has nothing in common with the Modigliani-Miller proposition, except the trivial relation that something doesn't matter. In the Modigliani-Miller theorem, it is capital structure, and in the Barro theorem it is government deficit. In my view, Barro's theorem, despite its elegance, has no substance. I don't understand why so many seem to be persuaded by a proposition whose proof rests on the incredible assumption that everybody cares about his heirs as if they were himself. If you drop that assumption, there is no proof based on rational behavior, and the theorem is untenable. But that kind of behavior is very rare and can't be universal. Just ask yourself what would happen with two families, when one family has no children and another family has 10 . Under Ricardian equivalence, both families would be indifferent between using 
taxes or deficit financing. But it is obvious that the no-children family would prefer the deficit, and the other would presumably prefer taxation. Indeed, why should the no-children-family save more, when the government runs a deficit? I am just sorry that any parallel is made between Modigliani-Miller and Ricardian equivalence.

I have in fact offered concrete empirical evidence, and plenty of it, that government debt displaces capital in the portfolio of households and hence in the economy. My paper is a bit old, though it has been replicated in unpublished research. But there is an episode in recent history that provides an excellent opportunity to test Barro's model of no burden against the life-cycle hypothesis measure of burden - the displacement effect. I am referring to the great experiment unwittingly performed by Reagan cutting taxes and increasing expenditure between 1981 (the first Reagan budget) and 1992. The federal debt increased $3 \frac{1}{4}$ times or from $7 \%$ of initial private net worth to about $30 \%$. In the same interval, disposable (nominal) personal income grew $117 \%$ (all data from the Economic Report of the President, 1994, Table B-112 and B-28). According to my model, private wealth is roughly proportional to net-of-tax income, and hence it should also have increased by $117 \%$, relative to the initial net worth. But net national wealth (net worth less government debt, which represents essentially the stock of productive private capital) should have increased $117 \%$ minus the growth of debt, or $117-23=94 \%$ (of initial net worth). The $23 \%$ is the crowding-out effect of government debt, according to the life-cycle hypothesis. The actual growth of national wealth turns out to be $88 \%$, pretty close to my prediction of $94 \%$. On the other hand, if the government debt does not crowd out national wealth, as Barro firmly holds, then the increase in the latter should have been the same as that of income, or $117 \%$ compared with $88 \%$. Similarly for Barro the growth of private net worth should be the growth of income of $117 \%$ plus the $23 \%$ growth of debt, or $140 \%$. The actual growth is $111 \%$, very close to my prediction of $117 \%$ and far from his, and the small deviation is in the direction opposite to that predicted by Barro. Why do so many economists continue to pay so much attention to Barro's model over the life-cycle hypothesis?

Solow: OK, let's move on. I think the next thing we ought to discuss is your Presidential Address to the American Economic Association and how, in your mind, it relates both to the 1944 paper that you've been talking about and your later work.

Modigliani: As I said before about Keynes, I stick completely to my view that to maintain a stable economy you need stabilization policy. Fiscal policy should, first of all, come in as an automatic stabilizer. Secondly, fiscal policy might enter in support of monetary policy in extreme conditions. But normally we should try to maintain full employment with savings used to finance investment, not to finance deficits. We should rely on monetary policy to ensure full employment with a balanced budget. But one thing I'd like to add is that it seems to me that in the battle between my recommendation to make use of discretion (or common sense) and Friedman's recommendation to renounce discretion in favor of blind rules (like 3\% money growth per year), my prescription has won hands down. There is not a country in the world today that uses a mechanical rule. 


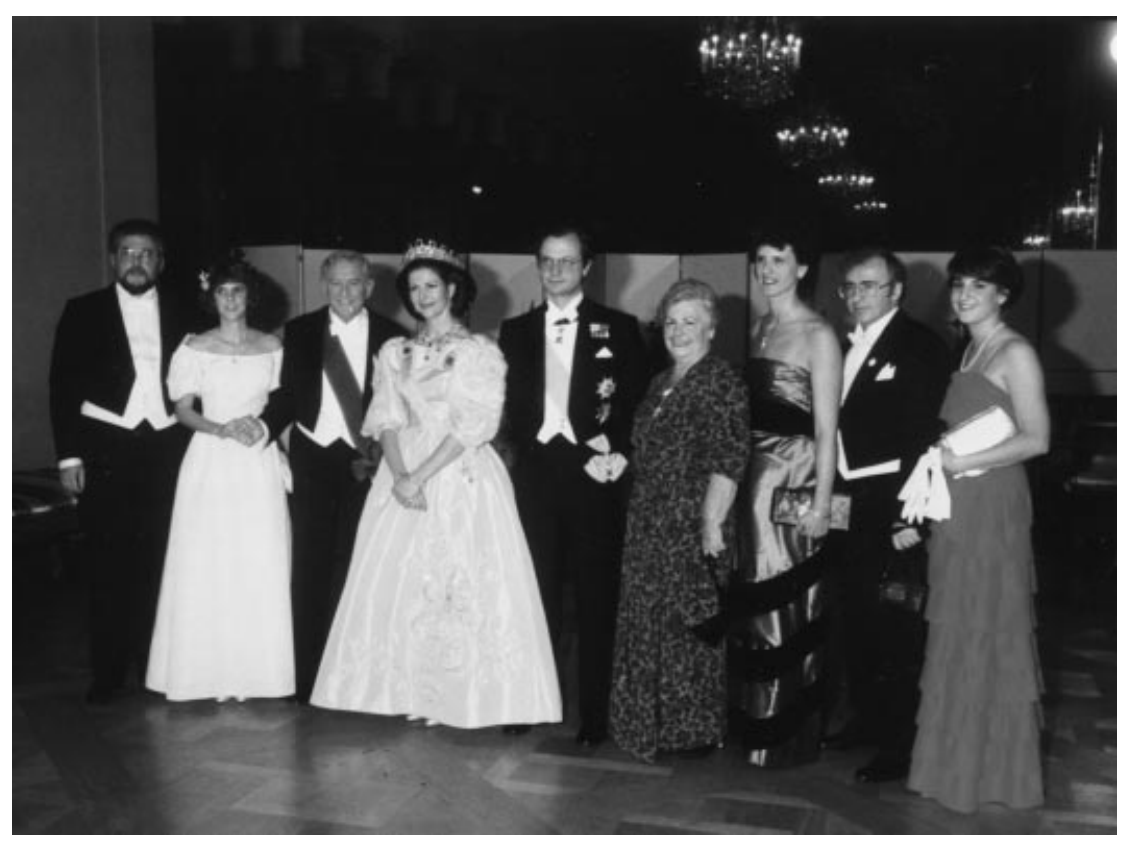

Figure 4. In Stockholm in 1985 after receiving the Nobel Prize. Left to right are Sergio Modigliani (son), Leah Modigliani (granddaughter), Franco Modigliani, Queen Silvia of Sweden, King Gustav Adolph of Sweden, Serena Modigliani (wife), Suzanne Modigliani (wife of Sergio), Andre Modigliani (son), and Julia Modigliani (granddaughter).

Solow: It's hard to imagine in a democratic country.

Modigliani: There is not a country that doesn't use discretion.

Solow: You know, I agree with you there. How would you relate the view of your Presidential Address to monetarism? It was stimulated by monetarism, in a way. How do you look at old monetarism, Milton Friedman's monetarism, now?

Modigliani: If by monetarism one means money matters, I am in agreement. In fact, my present view is that real money is the most important variable. But I think that a rigid monetary rule is a mistake. It is quite possible that in a very stable period, that might be a good starting point, but I would certainly not accept the idea that that's the way to conduct an economic policy in general.

Solow: And hasn't Milton sometimes, but not always, floated the idea that he can find no interest elasticity in the demand for money.

Modigliani: I've done several papers on that subject and rejected that claim all over the place. Anybody who wants to find it, finds it strikingly—absolutely no problem.

Solow: You had a major involvement in the development of the Federal Reserve's MPS quarterly macroeconometric model, but not lately. How do you feel about large econometric models now? There was a time when someone like Bob Hall 
might have thought that that's the future of macroeconomics. There is no room for other approaches. All research will be conducted in the context of his model.

Modigliani: Right. Well, I don't know. I imagine that, first of all, the notion of parsimoniousness is a useful notion, the notion that one should try to construct models that are not too big, models that are more compact in size. I think that at the present time these models are still useful. They still give useful forecasts and especially ways of gauging responses to alternative policies, which is most important. But under some international circumstances, there is no room for domestic monetary policy in some countries. In such a country, an econometric model may not be very helpful. But an econometric model would be somewhat useful in considering different fiscal policies.

Barnett: Has mentoring younger economists been important to you as your fame grew within the profession?

Modigliani: My relation with my students, which by now are legion, has been the best aspect of my life. I like teaching but I especially like working with students and associating them with my work. Paul Samuelson makes jokes about the fact that so many of my articles are coauthored with so many people that he says are unknown - such as Paul Samuelson himself. The reason is that whenever any of my research assistants has developed an interesting idea, I want their names to appear as coauthors. Many of my "children" now occupy very high positions, including Fazio, the Governor of the Bank of Italy, Draghi, the Director General of the Treasury of Italy, Padoa Schioppa, a member of the Directorate of the European Central Bank, and Stan Fischer, Joe Stiglitz, and several past and current members of the Federal Reserve Board. All have been very warm to me, and I have the warmest feeling for them.

Solow: Now if you were giving advice to a young macroeconomist just getting a Ph.D., what would you say is the most fertile soil to cultivate in macroeconomics these days?

Modigliani: I think that these days, in terms of my own shifts of interest, I've been moving toward open-economy macroeconomics and especially international finance. It's a very interesting area, and it's an area where wage rigidity is very important. Now the distinction becomes very sharp between nominal wage rigidity and real wage rigidity.

Solow: Explain that.

Modigliani: With nominal wage rigidity, you will want floating exchange rates. With real rigidity, there's nothing you can do about unemployment. I've been looking at the experiences of countries that tried fixing exchange rates and countries that tried floating exchange rates, and I am finding that both experiences have not been good. Europe has been doing miserably.

Barnett: You have been an important observer of the international monetary system and the role of the United States and Europe in it, and I believe that you have supported the European Monetary Union. Would you comment on the EMS and the future of the international monetary system, in relation to what you think about the recent financial crises and the role that exchange rates have played in them. 
Modigliani: Yes, I have been a supporter of the Euro, but to a large extent for its political implications, peace in Europe, over the purely economic ones. However, I have also pointed out the difficulties in a system which will have fixed exchange rates and how, for that to work, it will require a great deal of flexibility in the behavior of wages of individual countries having differential productivity growth and facing external shocks. I have also pointed out that the union was born under unfavorable conditions, as the role of the central bank has been played, not legally but de facto, by the Bundesbank, which has pursued consistently a wrong overtight monetary policy resulting in high European unemployment. It has reached 12\% and sometimes even higher, and that policy is now being pursued to a considerable extent by the European Central Bank, which is making essentially the same errors as the Bundesbank. This does not promise too much for the near future.

Solow: What we're going to do now is switch over to talking about the lifecycle theory of savings, and what I'd like you to do is comment on the simplest life-cycle model, the one that you and Albert Ando used for practical purposes, with no bequests, etc.

Modigliani: Well, let me say that bequests are not to be regarded as an exception. Bequests are part of the life-cycle model. But it is true that you can go very far with assuming no bequests, and therefore it's very interesting to follow that direction. The model in which bequests are unimportant does produce a whole series of consequences which were completely unrecognized before the Modigliani-Brumberg articles. There were revolutionary changes in paradigm stemming from the lifecycle hypothesis. Fundamentally, the traditional theory of saving reduced to: the proportion of income saved rises with income, so rich people (and countries) save; poor people dissave. Why do rich people save? God knows. Maybe to leave bequests. That was the whole story, from which you would get very few implications and, in particular, you got the implication that rich countries save and poor countries dissave, an absurd concept since poor countries cannot dissave forever. No one can. But from the life-cycle hypothesis, you have a rich set of consequences. At the micro level, you have all the consequences of "Permanent Income," including the fact that consumption depends upon (is proportional to) permanent income, while saving depends basically on transitory income: The high savers are not the rich, but the temporarily rich (i.e., rich relative to their own normal income).

The difference between life-cycle and permanent income is that the latter treats the life span as infinite, while in the life-cycle model, lifetime is finite. For the purpose of analyzing short-term behavior, it makes no difference whether life lasts 50 years or forever. So you do have fundamentally the same story about the great bias that comes from the standard way of relating saving to current family income. But, in fact, in reality it does make a difference what the variability of income is in terms of short term versus long term. The marginal propensity to save of farmers is much higher than that of government employees, not because farmers are great savers, but because their income is very unstable. Other consequences that are very interesting include the fact, found from many famous surveys, that successive generations seem to be less and less thrifty, that is, save less and less at any given 
level of income. These conclusions all are consequences of the association between current and transitory income.

Then you have consequences in terms of the behavior of saving and wealth over the lifetime, and here is where the difference between life cycle and permanent income become important. With the life-cycle hypothesis, saving behavior varies over the person's finite lifetime, because with finite life comes a life cycle of income and consumption: youth, middle age, children, old age, death, and bequests. That's why there is little saving when your are very young. You have more saving in middle age, and dissaving when you are old. With infinite life, there is no life cycle. Aggregate saving reflects that life cycle and its interaction with demography and productivity growth, causing aggregate saving to rise with growth, as has been shown with overlapping generations models. All that has been shown to receive empirical support.

Solow: Dissaving and old age, as well?

Modigliani: Right. Now let me comment on that. Some people have spent a lot of time trying to show that the life-cycle model is wrong because people don't dissave in old age. That is because the poor guys have just done the thing wrong. They have treated Social Security contribution as if it were a sort of income tax, instead of mandatory saving, and they have treated pension as a handout, rather than a drawing down of accumulated pension claims. If you treat Social Security properly, measuring saving as income earned (net of personal taxes) minus consumption, you will find that people dissave tremendous amounts when they are old; they largely consume their pensions, while having no income.

Solow: They are running down their Social Security assets.

Modigliani: In addition to running down their Social Security assets, they also are running down their own assets, but not very much. Somewhat. But, if you include Social Security, wealth has a tremendous hump. It gets to a peak at the age of around 55-60 and then comes down quickly. All of these things have been completely supported by the evidence. Now, next, you do not need bequests to explain the existence of wealth, and that's another very important concept. Even without bequests, you can explain a large portion of the wealth we have. Now that does not mean there are no bequests. There are. In all my papers on the life-cycle hypothesis, there is always a long footnote that explains how to include bequests.

Solow: How you would include it, yes.

Modigliani: In such a way that it remains true that saving does not depend upon current income, but on life-cycle income. That ensures that the ratio of bequeathed wealth to income tends to remain stable, no matter how much income might rise. It is also important to recognize the macro implications of the life cycle, which are totally absent in the permanent-income hypothesis, namely, that the saving rate depends not on income, but on income growth. The permanent income hypothesis has nothing really to say; in fact, it has led Friedman to advance the wrong conclusion, namely that growth reduces saving. Why? Because growth results in expectations that future income will exceed current income. But with finite lifetime, terminating with retirement and dissaving, growth generates saving. 
Consider again the simplified case of no bequests. Then each individual saves zero over its life cycle. If there is no growth, the path of saving by age is the same as the path of saving over life: it aggregates to zero. But if, say, population is growing, then there are more young in their saving phase than old in the dissaving mode, and so, the aggregate saving ratio is positive and increasing with growth. The same turns out with productivity growth, because the young enjoy a higher life income than the retired. Quite generally, the life-cycle model implies that aggregate wealth is proportional to aggregate income: hence the rate of growth of wealth, which is saving, tends to be proportional to the rate of growth of income. This in essence is the causal link between growth rate and saving ratio, which is one of the most significant and innovative implications of the life-cycle hypothesis.

Barnett: There has been much research and discussion about possible reforms or changes to the Social Security System. What are your views on that subject?

Modigliani: The problems of the Social Security System are my current highest interest and priority, because I think its importance is enormous; and I think there is a tragedy ahead, although in my view we can solve the problem in a way that is to everyone's advantage. In a word, we need to abandon the pay-as-you-go system, which is a wasteful and inefficient system, and replace it with a fully funded system. If we do, we should be able to reduce the Social Security contribution from the $18 \%$ that it would have to be by the middle of the next century, to below $6 \%$ using my approach, and I have worked out the transition. It is possible to go from here to there without any significant sacrifices. In fact, it can be done with no sacrifice, except using the purported surplus to increase national saving rather than consumption. And given the current low private saving rate and huge (unsustainable) capital imports, increasing national saving must be considered as a high priority.

Barnett: Are there any other areas to which you feel you made a relevant contribution that we have left out?

Modigliani: Perhaps that dealing with the effects of inflation. At a time when, under the influence of rational expectations, it was fashionable to claim that inflation had no real effects worth mentioning, I have delighted in showing that, in reality, it has extensive and massive real effects; and they are not very transitory. This work includes the paper with Stan Fisher on the effects of inflation, and the paper with Rich Cohen showing that investors are incapable of responding rationally to inflation, basically because of the (understandable) inability to distinguish between nominal and Fisherian real interest rates. For this reason, inflation systematically depresses the value of equities.

I have also shown that inflation reduces saving for the same reason. Both propositions have been supported by many replications. In public finance, the calculation of the debt service using the nominal instead of the real rate leads to grievous overstatement of the deficit-to-income ratio during periods of high inflation, such as the mid-seventies to early eighties in the presence of high debt-to-income ratios. In corporate finance, it understates the profits of highly levered firms. 


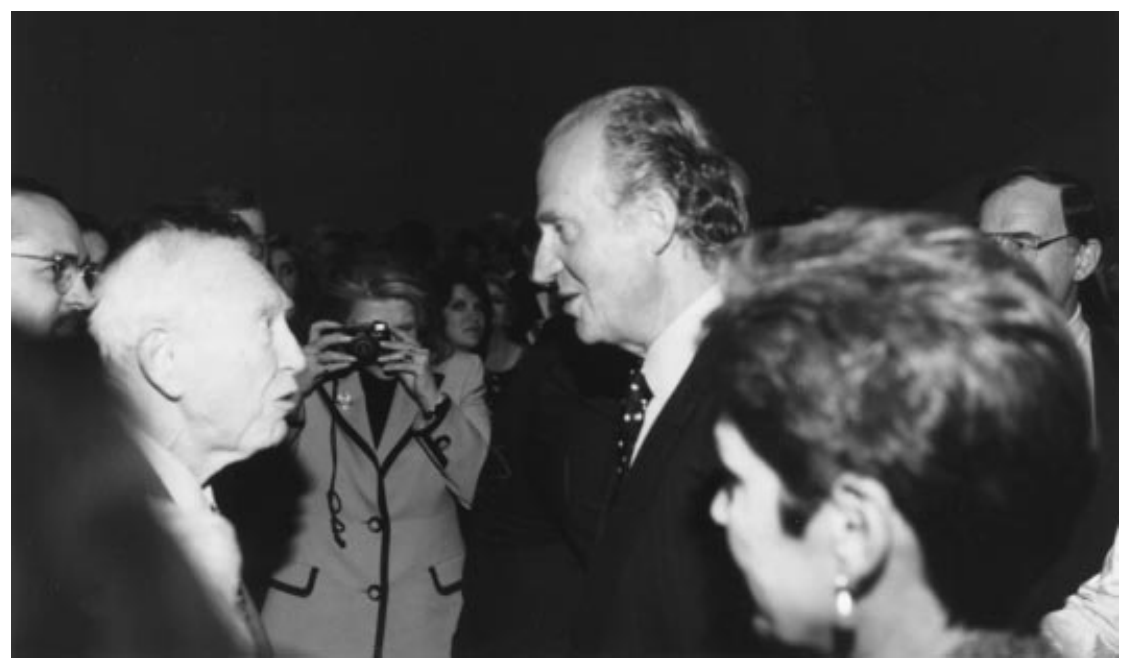

Figure 5. At the Kennedy Library in Boston in the spring of 1998 talking with the King of Spain.

Barnett: Your public life has been very intense, at least starting at some point in your life. I presume that you do not agree with Walras, who believed that economists should be technical experts only, and should not be active in the formation of policy. Would you comment on the role of economists as "public servants"?

Modigliani: I believe that economists should recognize that economics has two parts. One is economic theory. One is economic policy. The principles of economic theory are universal, and we all should agree on them, as I think we largely do as economists. On economic policy, we do not necessarily agree, and we should not, because economic policy has to do with value judgments, not about what is true, but about what we like. It has to do with the distribution of income, not just total income. So long as they are careful not to mix the two, economists should be ready to participate in policy, but they should be careful to distinguish what part has to do with their value judgment and what part with knowledge of the working of an economy.

Barnett: You have been repeatedly involved in advocating specific economic policies. Were there instances in which, in your view, your advice had a tangible impact on governments and people.

Modigliani: Yes, I can think of several cases. The first relates to Italy and is a funny one. Through the sixties and seventies, Italian wage contracts had an escalator clause with very high coverage. But in 1975, in the middle of the oil crisis, the unions had the brilliant idea of demanding a new type of escalator clause in which an $x \%$ increase in prices would entitle a worker to an increase in wages not of $x \%$ of his wage but of $x \%$ of the average wage - the same number of liras for everyone! And the high-wage employers went along with glee! I wrote a couple of indignant articles trying to explain the folly and announcing doomsday. To my surprise, it took quite a while before my Italian colleagues came to my 
support. In fact, one of those colleagues contributed a "brilliant" article suggesting that the measure had economic justification, for, with the high rate of inflation of the time, all real salaries would soon be roughly the same, at which time it was justified to give everyone the same cost-of-living adjustment! It took several years of economic turmoil before the uniform cost-of-living adjustment was finally abolished and its promoters admitted their mistake. It took until 1993 before the cost-of-living adjustment was abolished all together.

A second example is the recommendations in the 1996 book by two coauthors and me, Il Miracolo Possibile [The Achievable Miracle], which helped Italy to satisfy the requirement to enter the Euro. This, at the time, was generally understood to be impossible, because of the huge deficit, way above the permissible $3 \%$. We argued that the deficit was a fake, due to the use of inflation-swollen nominal interest rates in the presence of an outlandish debt-to-income ratio $\left(1 \frac{1}{4}\right)$, but the target was achievable through a drastic reduction of inflation and corresponding decline in nominal rates. This could be achieved without significant real costs by programming a minimal wage and price inflation through collaboration of labor, employer, and government. It worked, even beyond the results of the simulations reported in the book! And Italy entered the Euro from the beginning.

A third example is my campaign against European unemployment and the role played by a mistaken monetary policy. "An Economists' Manifesto on Unemployment in the European Union," issued by me and a group of distinguished European and American economists, was published a little over a year ago. Although it is not proving as effective as we had hoped, it is making some progress.

Finally, I hope that our proposed Social Security reform will have a significant impact. Here the stakes are truly enormous for most of the world, but the payoff remains to be seen.

\section{SELECTED SCIENTIFIC PUBLICATIONS OF FRANCO MODIGLIANI}

\section{BOOKS}

\section{3}

National Incomes and International Trade, with Hans Neisser. Chicago: University of Illinois Press.

\section{6}

Ricerca Operativa [collection of lectures on operations research given at the Istituto Superiore per la Direzione Aziendale, Rome]. Rome: C.I.A.A.

Problems of Capital Formation: Concepts, Measurements and Controlling Factors, Studies in Income and Wealth, Vol. 19, National Bureau of Economics Research (editor and contributor). Princeton, NJ: Princeton University Press.

\section{0}

Planning Production, Inventories and Work Forces, with Charles C. Holt, John F. Muth, and Herbert S. Simon. New York: Prentice-Hall. 


\section{1}

The Role of Anticipations and Plans in Economic Behavior and Their Use in Economic Analysis and Forecasting, Studies in Business Expectations and Planning, No. 4, Bureau of Economic and Business Research, with Kalman J. Cohen. Chicago: University of Illinois.

\section{5}

Mercato del Lavoro, Distribuzione del Reddito e Consumi Privati, with Ezio Tarantelli. Bologna: il Mulino.

New Mortgage Designs for Stable Housing in an Inflationary Environment, Conference Series No. 14, edited with Donald Lessard. Boston: Federal Reserve Bank of Boston.

\section{0}

The Collected Papers of Franco Modigliani: Essays in Macroeconomics (Vol. 1); The Life Cycle Hypothesis of Saving (Vol. 2); The Theory of Finance and Other Essays (Vol. 3), edited by Andrew Abel; Monetary Theory and Stabilization Policies (Vol. 4); Savings, Deficits, Inflation, and Financial Theory (Vol. 5), edited by Simon Johnson. Cambridge, MA: MIT Press.

\section{3}

The Determinants of National Saving and Wealth [proceedings of a conference held by the International Economic Association at Bergamo, Italy, 1980], edited with Richard Hemming. London: Macmillan.

\section{6}

The Debate over Stabilization Policy, edited by Franco Bruni. Cambridge: Cambridge University Press. Il caso Italia. Milan: Edizioni di Communità.

\section{7}

Reddito, Interesse, Inflazione, edited by Tommaso and Fiorella Padoa-Schioppa. Turin: Einaudi.

\section{2}

Capital Markets, Institutions and Instruments, with Frank Fabozzi. New York: Prentice-Hall.

Mortgage and Mortgage-Backed Securities Markets, with Frank Fabozzi. Cambridge, MA: Harvard Business School Press.

Consumo, Risparmio, Finanza [selections from the Collected Papers], edited by Carlo D'Adda. Bologna: il Mulino.

\section{5}

The Italian Economy: What Next?, edited with Mario Baldassarri. London: Macmillan.

Dialogo Tra un Professore e La Banca D'Italia, with Carli and Paolo Baffi. Florence: Vallecchi Editore.

\section{6}

Il Miracolo Possibile, with Mario Baldassarri and Fabio Castiglionesi. Rome: Laterza \& Figli Spa. 


\section{8}

Foundations of Financial Markets and Institutions, with Frank J. Fabozzi and Michael G. Ferri. New York: Prentice-Hall.

1999

Avventure di un economista: La mia vita, le mie idee, la nostra epoca [a cura di Paolo Peluffo]. Rome: Laterza \& Figli Spa.

\section{ARTICLES}

\section{4}

Liquidity preference and the theory of interest and money. Econometrica 12, 45-88.

\section{7}

L'Organizzazione e la direzione della produzione in un economia socializzata, Giornale degli Economisti.

\section{9}

Fluctuations in the saving-income ratio: A problem in economic forecasting. In Studies in Income and Wealth, Vol. 11, pp. 371-443. New York: National Bureau of Economic Research.

Liquidity and uncertainty_discussion. American Economic Review 34, 201-208.

New areas of opinion research: Economics. Public Opinion Quarterly 949-950.

\section{2}

The effect of availability of funds and the terms thereof on business investment, with M. Zeman. In Conference on Research in Business Finance, Washington, DC: National Bureau of Economic Research.

The measurement of expectation (abstract). Econometrica 20.

\section{4}

The predictability of social events, with E. Grunberg. Journal of Political Economy 62, 465-478.

Utility analysis and the consumption function: An interpretation of cross-section data, with R. Brumberg. In K.K. Kurihara, ed., Post-Keynesian Economics, pp. 388-436. New Brunswick, NJ: Rutgers.

\section{5}

Economic expectations and plans of firms in relation to short term forecasting, with O.H. Sauerlender. In Studies in Income and Wealth, Vol. 17, Short-Term Economic Forecasting, Princeton, NJ: Princeton University Press.

A linear decision rule for production and employment scheduling, with C.C. Holt and H.A. Simon. Management Science. 
Production planning over time and the nature of the expectation and planning horizon, with F.E. Hohn. Econometrica 23, 46-66.

\section{6}

Derivation of a linear decision rule for employment and production, with C.C. Holt and J.F. Muth. Management Science.

\section{7}

Business reasons for holding inventories and their macro-economic implications. In Problems of Capital Formation: Concepts, Measurement and Controlling Factors, 19, pp. 495-511. Princeton, NJ: NBER and Princeton University Press.

Private investment in the electric power industry and the acceleration principle, with A. Kisselgoff. Review of Economics and Statistics 39, 363-379.

Tests of the life cycle hypothesis of savings: Comments and suggestions, with A.K. Ando. Bulletin of the Oxford University Institute of Statistics 99-124.

\section{8}

The cost of capital, corporation finance and the theory of investment, with M.H. Miller. American Economic Review 48, 261-297.

Forecasting uses of anticipatory data on investment and sales, with H.M. Weingartner. Quarterly Journal of Economics 72, 23-54.

Mathematics for production scheduling, with M. Anshen, et al. Harvard Business Review 36.

New developments on the oligopoly front, Journal of Political Economy 66, 215-232.

Preface to "Employers' forecasts of manpower requirements: A case study," by Robert Ferber, Studies in Business Expectations and Planning, Vol. 3, pp. 3-5. Bureau of Economic and Business Research, Urbana: University of Illinois.

The significance and uses of ex ante data, with K.L. Cohen. In M.J. Bowman, ed., Expectations, Uncertainty and Business Behavior, pp. 151-164. Social Science Research Council.

\section{9}

"The cost of capital, corporation finance and the theory of investment": Reply, with M.H. Miller. American Economic Review 49, 655-669.

Economic analysis and forecasting: Recent developments in use of panel and other survey techniques, with F.E. Balderston. In E. Burdick and A.J. Brodbeck, eds., American Voting Behavior, pp. 372-398. Glencoe, IL: Free Press.

"Forecasting uses of anticipatory data on investment and sales": Reply, with H.M. Weingartner. Quarterly Journal of Economics 73.

Growth, fluctuations and stability, with A.K. Ando. American Economic Review 49, 501-524.

"New developments on the oligopoly front": Reply, Journal of Political Economy 67.

\section{0}

Postscript to Economic analysis and forecasting: Recent developments in use of panel and other survey techniques. In H. Hazlitt, ed., Critics of Keynesian Economics, pp. 183-184. Van Nostrand. 
The source of regressiveness in surveys of businessmen's short run expectations, with John Bossons. In The Quality and Economic Significance of Anticipation Data, pp. 239-262. Princeton, NJ: Princeton University Press and National Bureau of Economic Research.

The 'permanent income' and the 'life cycle' hypothesis of saving behavior: Comparison and tests, with A.K. Ando. In Consumption and Saving, Vol. 2, pp. 74-108, 138-147. Wharton School of Finance and Commerce, University of Pennsylvania.

\section{1}

Dividend policy, growth, and the valuation of shares, with M.H. Miller, Journal of Business 34, 41-43.

Firm costs structures and the dynamic responses of inventories, production, work force and orders to sales fluctuations, with C.C. Holt. In Inventory Fluctuations and Economic Stabilization, Part II: Causative Factors in Movements of Business Inventories, pp. 3-50. Washington, DC: U.S. Government Printing Office.

Long run implications of alternative fiscal policies and the burden of the national debt. Economic Journal 71, 728-755.

\section{2}

Il rapporto tra indebitamento e patrimonio, la politica dei dividendi ed il costo del capitale, with M.H. Miller. Studi Economici 17, 3-25.

Implicazioni a lungo periodo di politiche fiscali alternative e l'onere del debito pubblico. Moneta $e$ Credito 58, 3-40.

\section{3}

Economic forecasting when the subject of the forecast is influenced by the forecast: Comment, with

E. Grunberg, American Economic Review 53, 734-737.

The 'life cycle' hypothesis of saving: Aggregate implications and tests, with A.K. Ando. American Economic Review 53, 55-84, Part I.

The monetary mechanism and its interaction with real phenomena. Review of Economics and Statistics 45, 79-107, Part II, Supplement.

\section{4}

Comment on "A postwar quarterly model: Description and applications," by L.R. Klein. In Models of Income Determination, Vol. 20, Studies in Income and Wealth, pp. 41-53. National Bureau of Economic Research.

Comment on "A survey of some theories of income distribution," by T. Scitovsky. In The Behavior of Income Shares, Vol. 27, Studies in Income and Wealth, pp. 39-51. National Bureau of Economic Research.

A critique of central banking in the United States-Discussion. Annual Report, pp. 24-29. Boston: Federal Reserve Bank.

Economic forecasting when the subject of the forecast is influenced by the forecast: Correction, with E. Grunberg, American Economic Review 54, Part 1.

How to make a burden of the public debt: A reply to mishan. Journal of Political Economy 52, 483-485.

Monetary policy and the rate of economic activity: A project of the Committee on Economic Stability. Items 18, 36-38.

Some empirical tests of monetary management and of rules versus discretion. Journal of Political Economy 72, 211-245. 


\section{5}

Discussion: Reflexive prediction, with E. Grunberg. Philosophy of Science 32, 173-174.

The relative stability of monetary velocity and the investment multiplier, with A.K. Ando. American Economic Review 55, 693-728.

\section{6}

Épargne et consommation en avenir aléatoire, with J.H. Drèze. Cahiers du Seminaire d'Econometrie $9,7-33$.

Innovations in interest rate policy, with R. Sutch. American Economic Review 56, 178-197.

The life cycle hypothesis of saving, the demand for wealth and the supply of capital. Social Research 33, 160-217.

The Pasinetti paradox in neoclassical and more general models, with P.A. Samuelson. Review of Economic Studies 33, 269-301.

Research on the links between monetary policy and economic activity: A progress report of a subcommittee of the Committee on Economic Stability. Items 20, 7-8.

Some estimates of the cost of capital to the electric utility industry, 1954-57, with M.H. Miller. American Economic Review 56, 333-391.

Statistical vs. structural explanations of understatement and regressivity in "rational" Expectations, with John Bossons. Econometrica 34, 347-353.

$\mathrm{Su}$ alcuni aspetti della congiuntura e della politica monetaria italiana nell' ultimo quinquennio, with G. LaMalfa. Moneta e Credito 19, 211-257.

A suggestion for solving the international liquidity problem, with P. Kenen. Banca Nazionale del Lavore Quarterly Review 76, 3-17.

\section{7}

Debt management and the term structure of interest rates: An empirical analysis, with R. Sutch. Journal of Political Economy 74, 569-589, Part II.

Estimates of the cost of capital relevant for investment decisions under uncertainty, with M.H. Miller. In R. Ferber, ed., Determinants of Investment Behavior, Vol. 18, pp. 179-214. Universities-National Bureau Committee for Economic Research, New York: Columbia University Press.

Inflation, balance of payments deficit and their cure through monetary policy: The Italian example, with G. LaMalfa. Banca Nazionale del Lavoro Quarterly Review 80, 3-47.

\section{8}

Liquidity preference. In D.L. Sills, ed., International Encyclopedia of the Social Sciences, Vol. 9, pp. 394-409. Cromwell, Collier and Mcmillan.

The transmission of demand fluctuations through a distribution and production system, the TV-set industry, with C.C. Holt and J.P. Shelton. Canadian Journal of Economics 1, 718-739.

\section{9}

Econometric analysis of stabilization policies, with A.K. Ando, American Economic Review 59, 296314.

The term structure of interest rates: A re-examination of the evidence, with R. Sutch. Journal of Money, Credit, and Banking 1, 112-120.

A theory and test of credit rationing, with D.M. Jaffee. American Economic Review 59, 850-872. 


\section{0}

Central bank policy, the money supply, and the short-term rate of interest, with R. Rasche and J.P. Cooper. Journal of Money, Credit and Banking 2, 166-218.

The life cycle hypothesis of saving and intercountry differences in the saving ratio. In W.A. Eltis, M.F. Scott, J.N. Wolfe, eds., Induction, Growth and Trade: Essays in Honour of Sir Roy Harrod, pp. 197-225. Oxford: Clarendon Press.

\section{1}

Curva di Phillips, sottosviluppo e disoccupazione strutturale, with E. Tarantelli. Quaderni di Ricerche 9, Ente Per Gli Studi Monetari, Bancari e Finanziari Luigi Einaudi, October 1971.

Monetary policy and consumption: Linkages via interest rate and wealth effects in the FMP Model. In Consumer Spending and Monetary Policy: The Linkages, Vol. 5, pp. 9-84. Boston: Federal Reserve Bank.

The reform of the International Payments System, with H. Askari. In Essays in International Finance, Vol. 89, pp. 3-28. Princeton, NJ: Princeton University.

Some proposals for a reform of the discount window. Reappraisal of the Federal Reserve Discount Mechanism, Vol. 2, pp. 59-76. Board of Governors of the Federal Reserve System.

\section{2}

Appendix to Part One: Equations and definitions of variables for the FRB-MIT-Penn econometric model, November 1969, with A. Ando and R. Rasche. In B.G. Hickman, ed., Econometric Models of Cyclical Behavior, Vol. 36, Studies in Income and Wealth, pp. 543-598. National Bureau of Economic Research.

Consumption decisions under uncertainty, with J. Drèze. Journal of Economic Theory 5, 308-335.

The dynamics of portfolio adjustment and the flow of savings through financial intermediaries. In E.M. Gramlich and D.M. Jaffee, eds., Savings Deposits, Mortgages, and Housing: Studies for the Federal Reserve MIT Penn Econometric Model, pp. 63-102. Lexington Books.

Efficiency of European capital markets and comparison with the American market, with G. Pogue, M. Scholes, and B. Solnik. In The Stock Exchange: How to Make it an Instrument of EconomicSocial Progress in Europe and in the World (Proceedings of the First International Conference of Stock Exchanges, Milan).

International capital movements, fixed parities, and monetary and fiscal policies. In J. Bhagwati and R. Eckaus, eds., Development and Planning: Essays in Honor of Paul Rosenstein-Rodan, pp. 239253. London: George Allen \& Unwin.

The International Payments System: Past, present and future, with H. Askari. Sloan Management Review 13, 1-16.

Stock market and economy—discussion. American Economic Review 229-233.

\section{3}

Import and export price indices, with H. Askari. Journal of Political Economy 12-43.

Inflation, rational expectations and the term structure of interest rates, with R.J. Shiller. Economica $12-43$.

The international transfer of capital and the propagation of domestic disturbances under alternative payment systems, with H. Askari. Banca Nazionale del Lavoro Quarterly Review 107, 3-18.

A generalization of the Phillips curve for a developing country, with E. Tarantelli. Review of Economic Studies 40, 203-223. 


\section{4}

An empirical analysis of the composition of financial wealth in Italy, with F. Cotula. Banca Nazionale del Lavoro Quarterly Review 109, 140-166.

On the role of expectations of price and technological change in an investment function, with A.K. Ando, R. Rasche, and S.J. Turnovsky. International Economic Review 15, 384-414.

The 1974 Report of the President's Council of Economic Advisors: A critique of past and prospective policies. American Economic Review 64, 544-557.

\section{5}

Alternative investment performance fee arrangements and implications for SEC regulatory policy, with G.A. Pogue. Bell Journal of Economics 6, 127-160.

An introduction to risk and return: Concepts and evidence, Part I, with G.A. Pogue, Financial Analysts Journal; Part II, Financial Analysts Journal. Parts I and II reprinted in S.N. Levine, ed., Financial Analysts' Handbook I: Portfolio Management, pp. 1296-1342. Dow Jones-Irwin.

The channels of monetary policy in the Federal Reserve-MIT-University of Pennsylvania econometric model of the United States, in G.A. Renton, ed., Modelling the Economy, pp. 240-267. London: Heinemann Educational Books.

The consumption function in a developing economy and the Italian experience, with E. Tarantelli. American Economic Review 65, 825-842.

Inflation and the housing market: Problems and potential solutions, with Donald Lessard. In Donald Lessard and Franco Modigliani, eds., New Mortgage Designs for Stable Housing in an Inflationary Environment, Vol. 14, pp. 13-45. Boston: Federal Reserve Bank. Reprinted in Sloan Management Review 17.

The life cycle hypothesis of saving twenty years later. In M. Parkin and A.R. Nobay, eds., Contemporary Issues in Economics: Proceedings of Annual Conference of Association of University Teachers of Economics, pp. 2-36. Manchester University Press.

Rediscovery of money-discussion. American Economic Review 65, 179-181.

Some reflections on describing structures of finance sectors, with A.K. Ando, and Appendix, with K. Shell. In G. Fromm and R. Klein, eds., The Brookings Model: Perspective and Recent Developments, pp. 524-563. New York: North Holland/American Elsevier.

Targets for monetary policy in the coming year, with Lucas Papademos. Brookings Papers on Economic Activity 1, 141-163.

\section{6}

Crisi Economica e Crisi Politica 22, pp. 23-28. Rome: Quaderni del l'Associazione Salvemini.

Impacts of fiscal actions on aggregate income and the monetarist controversy: Theory and evidence, with A.K. Ando, with the assistance of J. Giangrande. In J.L. Stein, ed., Monetarism, Studies in Monetary Economy, pp. 17-42. Amsterdam: North-Holland.

Models of the economy and optimal stabilization policies. In Sydney Shulman, ed., Mathematical Models in Economics: Papers and Proceedings of a US-USSR Seminar (June 16-18, 1976, Moscow), pp. 211-244. Washington, DC: National Bureau of Economic Research.

Monetary policy for the coming quarters: The conflicting views, with Lucas Papademos. New England Economic Review 2-35.

Some currently suggested explanations and cures for inflation: A comment. In K. Brunner and A.H. Meltzer, eds., Institutional Arrangements and the Inflation Problem, Vol. 3, Series on Public Policy, pp. 179-184. Amsterdam: North-Holland.

Some economic implications of the indexing of financial assets with special reference to mortgages, In Mario Monti, ed., The New Inflation and Monetary Policy, pp. 90-116. London and Basingstoke: Macmillan. 


\section{7}

Comment on "Investment, interest rates, and the effects of stabilization policies," by R.E. Hall. Brookings Papers on Economic Activity 1, 107-112.

Is a tax rebate an effective tool for stabilization policy?, with C. Steindel. Brookings Papers on Economic Activity 1, 175-209.

Market forces, trade union action, and the Phillips curve in Italy, with E. Tarantelli. Banca Nazionale Del Lavoro Quarterly Review 3-36.

The monetarist controversy (a seminar discussion, and discussion with M. Friedman, Federal Reserve Bank of San Francisco). Economic Review Supplement 5-26.

The monetarist controversy or, should we forsake stabilization policies? (Presidential Address delivered at the American Economic Association, September 17, 1976). American Economic Review 67(2), $1-19$.

A note on capital movements and the relation of the spread in spot and forward rates to variations in the short-term interest differential, with H. Askari. Kyklos 30, 38-50.

Should control theory be used for economic stabilization?: A comment. In K. Brunner and A.H. Meltzer, eds., Optimal Policies, Control Theory and Technology Exports, Vol. 7, pp. 85-91. Amsterdam: North-Holland.

\section{8}

Comment on "Efficient-market theory: Implications for monetary policy," by F.S. Mishkin. Brookings Papers on Economic Activity 3, 757-762.

Discussion on "Inflation and unemployment in a macro-econometric model," by R.C. Fair. In After the Phillips Curve: Persistence of High Inflation and High Unemployment, Vol. 19, 194-200. Boston: Federal Reserve Bank.

Implications for policy: A symposium. Brookings Papers on Economic Activity 2, 514-518 (A special issue on Innovative Policies to Slow Inflation). Reprinted in A. Okun and G. Perry, eds., Curing Chronic Inflation, pp. 278-282. Washington, DC: Brookings Institution.

The management of an open economy with "100\% plus" wage indexation, with T. Padoa-Schioppa. Essays in International Finance 130, 1-43.

Optimal demand policies against stagflation, with Lucas Papademos. Weltwirtschafiches Archiv: Review of World Economics 114, 736-782.

Towards an understanding of the real effects and costs of inflation, with Stanley Fischer. Review of World Economics: Journal of the Kiel Institute of World Economics 114, 810-832.

\section{9}

Comment on "On modeling the economic linkages among countries," by R.C. Fair. In Rudiger Dornbusch and J. Frenkel, eds., International Economic Policy, Theory and Evidence, pp. 239-242. Baltimore, MD: Johns Hopkins University Press.

Coupon and tax effects on new and seasoned bond yields and the measurement of the cost of debt capital, with Robert J. Shiller. Journal of Financial Economics 7, 297-318.

Determinanti strutturali e transitorie della mobilità del lavoro, "la congettura di Holt" e l'esperienza italiana, with E. Tarantelli. Banca Nazionale del Lavoro Quarterly Review 123-148.

Effetti dell'inflazione sui mercati finanziari. Associazione per lo Sviluppo degli Studi dei Banca e Borsa 19, 3-16.

The financial goal of the firm in a market economy. European Federation of Financial Analysts Societies, Bulletin 13, 100-102.

Has the economist lost control of the economy? (stated meeting report). Bulletin of the American Academy of Arts and Sciences 32, 38-49. 
Inflation, rational valuation and the market, with R.A. Cohn. Financial Analysts Journal 24-44.

Structural and transitory determinants of labour mobility: "Holt's conjecture" and Italian Experience, with E. Tarantelli. Banca Nazionale del Lavoro Quarterly Review 205-226.

\section{0}

Comment on "The central role of credit crunches in recent financial history," by A.M. Wojnilower. Brookings Papers on Economic Activity 2, 332-337.

Comment on "The determination of long-term interest rates: Implications for fiscal and monetary policies," by B. Friedman. Journal of Money, Credit and Banking 12(2, Special Issue), 370373.

The structure of financial markets and the monetary mechanism, with Lucas Papademos. Controlling Monetary Aggregates III, No. 23, pp. 111-155. Federal Reserve Bank of Boston.

The trade-off between real wages and employment in an open economy (Belgium), with Jacques H. Drèze, CORE, Université Catholique de Louvain, Discussion Paper 7947.

\section{1}

Una nova abordagem do mecanismo monetario e sue relacao com a estrutura financeira [The Monetary Mechanism Revisited and Its Relation to the Financial Structure]. Rivista de Econometria 1, 530.

\section{2}

Debt, dividend policy, taxes, inflation and market valuation (Presidential Address delivered at the American Finance Association). Journal of Finance 37, 255-273.

Inflation and the stock market, with R.A. Cohn, in J.A. Boeckh and R.T. Coghlan, eds., The Stock Market and Inflation, pp. 99-117. Dow Jones-Irwin.

Inflation-induced errors in stock market values-United States. In P. Grady, ed., Peering Under the Inflationary Veil, pp. 17-19. Economic Council of Canada.

\section{3}

Comment on "The nonadjustment of nominal interest rates: A study of the Fisher effect," by L.H. Summers. In J. Tobin, ed., Macroeconomics, Prices, and Quantities, Essays in Memory of Arthur M. Okun, pp. 241-244. Washington, DC: Brookings Institution.

Debt, dividend policy, taxes, inflation, and market valuation: erratum. Journal of Finance 38, 10411042 .

Determinants of private saving with special reference to the role of Social Security-cross-country tests, with A. Sterling. In F. Modigliani and R. Hemming, eds., The Determinants of National Saving and Wealth, pp. 24-55. London: Macmillan.

Discussion of "Investment versus savings incentives: The size of the bang for the buck and the potential for self-financing business tax cuts," by Alan J. Auerbach and Laurence J. Kotlikoff. In L.H. Meyer, ed., The Economic Consequences of Government Deficits, pp. 150-154. Boston: Kluwer-Nijhoff.

Government deficits, inflation, and future generations. In D.W. Conklin and T.J. Courchene, eds., Deficits: How Big and How Bad?, pp. 55-57. Ontario Economic Council Special Research Report, Ontario Economic Council.

Inflation, financial and fiscal structure, and the monetary mechanism, with Lucas Papademos. In G. de Ménil and R.J. Gordon, eds., European Economic Review 21, 203-250. 


\section{4}

Discussion of "Retirement annuity design in an inflationary climate," by Z. Bodie and J.E. Pesando. In Z. Bodie and J. Shoven, eds., Financial Aspects of the United States Pension System. Chicago: The University of Chicago Press.

Franco Modigliani. In A. Klamer, ed., Conversations with Economists: New Classical Economists and Opponents Speak Out on the Current Controversy in Macroeconomics, pp. 114-126. Totowa, NJ: Rowman \& Allanheld.

\section{5}

Comment on "Changes in the balance sheet of the U.S. manufacturing sector," by J.H. Ciccolo, Jr., and C.F. Baum. In Benjamin M. Friedman, ed., Corporate Capital Structures in the United States, pp. 109-115. Chicago: National Bureau of Economic Research Project Report and University of Chicago Press.

Franco Modigliani. In M. Blaug, ed., Great Economists Since Keynes: An Introduction to the Lives and Works of 100 Modern Economists, pp. 169-171. Wheatsheaf Books.

The impact of fiscal policy and inflation on national saving: The Italian case, with Tullio Jappelli and M. Pagano. Banca Nazionale del Lavoro Quarterly Review 153, 91-126.

Inflation and corporate financial management, with R.A. Cohn. In E.I. Altman and M.G. Subrahmanyam, eds., Recent Advances in Corporate Finance, pp. 341-370. Homewood IL: R.D. Irwin.

Italy: Past experience with deindexation. In J. Williamson, ed., Inflation and Indexation: Argentina, Brazil, and Israel, pp. 118-121. Cambridge, MA: MIT Press.

La prevedibilita degli eventi sociali [Foreseeable social events], with E. Grunberg. In I. Visco, ed., Le aspettative nell'analisi economica. Il Mulino.

The public spending deficit and the over-valued dollar. In Gianni Zandano, ed., Theme: The International Monetary System and Economic Recovery, pp. 99-102. Torino: Istituto Bancario San Paolo.

\section{6}

Aggregate unemployment in Italy, 1960-1983, with F. Padoa Schioppa and N. Rossi. Economica 53, S245-S273.

Comment on "A non-Walrasian model of the business cycle," by Jean-Pascal Benassy. In R.H. Day and G. Eliasson, eds., The Dynamics of Market Economies. Amsterdam: North-Holland.

Conferencias 1985: XX Reunión Anual de la Asociación Argentina de Economía Política, with Stanley Fischer. Asociación de Bancos Argentinos, pp. 3-96. Buenos Aires.

Discussion in Symposium on Budget Balance: Do Deficits Matter?, pp. I.24-I.27. Washington, DC: Committee for a Responsible Budget.

Comment on "Government debt, government spending and private sector behavior," with A. Sterling. American Economic Review 76, 1168-1179.

Life cycle, individual thrift, and the wealth of nations. Les Prix Nobel, pp. 260-281. Stockholm: The Nobel Foundation.

Per una minore disoccupazione in Europa: Il ruolo della formazione di capitale, with M. Monti, J. Drèze, H. Giersch, and R. Layard. Giornale degli economisti e annali di economia.

\section{7}

Comments "Conventional valuation and the term structure of interest rates," by R.J. Shiller. In Rudiger Dornbusch, Stanley Fischer, and John Bossons, eds., Macroeconomics and Finance: Essays in Honor of Franco Modigliani. Cambridge MA: MIT Press. 
Comments on "1944, 1963, and 1985," by Stanley Fischer. In Rudiger Dornbusch, Stanley Fischer, and John Bossons, eds., Macroeconomics and Finance: Essays in Honor of Franco Modigliani, pp. 257-264. Cambridge, MA, and London: MIT Press.

The economics of public deficits. In A. Razin and E. Sadka, eds., Economic Policy in Theory and Practice (Conference at Tel Aviv University, May 1984), pp. 3-44. London: Macmillan.

Fiscal policy and saving in Italy since 1860, with Tullio Jappelli. In M.J. Boskin, J.S. Flemming, and S. Gorini, eds., Private Saving and Public Debt, pp. 126-170. New York: Basil Blackwell.

The growth of the federal deficit and the role of public attitudes, with A. Modigliani. Public Opinion Quarterly 51.

The key to saving is growth, not thrift. Challenge Magazine 24-29.

The Massachusetts model of profit regulation in nonlife insurance: An appraisal and extensions, with R.D. Hill. In J.D. Cummins and S.A. Harrington, eds., Fair Rate of Return in Property-Liability Insurance, pp. 27-53. Boston: Kluwer/Nijhoff.

Money, credit, and the monetary mechanism, with Lucas Papademos. In M. de Cecco and J. Fitoussi, eds., Monetary Theory and Economic Institutions, pp. 121-160. London: Macmillan.

\section{8}

The determinants of interest rates in the Italian economy, with Tullio Jappelli. Review of Economic Conditions in Italy, 9-34.

L'effetto della politica fiscale sul tasso di interesse, with Tullio Jappelli. Estratto da Economia Italiana $1,9-38$.

Measuring the contribution of intergenerational transfers to total wealth: Conceptual issues and empirical findings. In D. Kessler and A. Masson, eds., Modelling the Accumulation and Distribution of Wealth, pp. 21-52. Oxford: Clarendon Press.

MM-past, present, future. Journal of Economic Perspectives 2, 149-158.

The monetarist controversy revisited. Contemporary Policy Issues 6, 3-18.

Reagan's economic Policies. Oxford Economic Papers 40, 397-426.

The role of intergenerational transfers and life cycle saving in the accumulation of wealth. Journal of Economic Perspectives 2, 15-40.

World economic outlook and its implications for Italy. Italian Journal 2, 25-30.

\section{9}

Comment on Chapter 12. In G. diTella and Rudiger Dornbusch, eds., Political Economy of Argentina, 1946-83. Oxford: St. Anthony's College and Macmillan.

La hipoteca a prueba de inflación (IPM); la hipoteca para los jóvenes. Cuadernos Económicos de ICE 42, 139-154.

L'impatto della politica fiscale e dell'inflazione sul risparmio nazionale: Una replica, with Tullio Jappelli and M. Pagano. Moneta e Credito, 261-266.

Riandando al mio passato, estratto da Moneta e Credito, Rivista Trimestrale della Banca Nazionale del Lavoro 168.

Testimony III: An interview. In G.R. Feiwel, ed., The Economics of Imperfect Competition and Employment: Joan Robinson and Beyond. New York: New York University Press.

\section{0}

Dividend decisions and earnings, with Paul M. Healy. Journal of Accounting, Auditing and Finance 5 (winter/spring), 3-25.

Inflation and finance. In S.G. Rhee and R.P. Chang, eds., Pacific-Basin Capital Markets Research, Vol. 2. Amsterdam: Elsevier. 
Il risparmio nel Mezzogiorno. Naples: Mezzogiorno d'Europa 10, 15-24; English translation, Saving in the Mezzogiorno of Italy. Naples: Journal of Regional Policy 10, 15-23.

Perché è diminuito il saggio di risparmio in Italia? with Tullio Jappelli. In Salvatore Biasco, Alessandro Roncaglia, and Michele Salvati, eds., Istituzioni e mercato nello sviluppo economico: Saggi in onore di Paolo Sylos Labini. Rome: Gius, Laterza \& Figli.

Recenti diminuzioni dei saggi di risparmio: Una prospettiva di ciclo vitale. Rivista di Politica Economica, 247-285.

The supply of money and the control of nominal income, with Lucas Papademos. In B.M. Friedman and F.H. Hahn, eds., Handbook of Monetary Economics, pp. 399-496b. Amsterdam: North-Holland.

\section{1}

The rules of the game and the development of security markets, with Enrico Perotti. In S.G. Rhee and R.P. Chang, eds., Pacific-Basin Capital Markets Research, Vol. 2, pp. 49-63. Amsterdam: Elsevier North-Holland.

\section{2}

Bonds market, with F. Fabozzi. In The New Palgrave Dictionary of Money and Finance, Vol. 1, pp. 213219. London: Macmillan.

Depository institution failures. In Rebuilding Public Confidence Through Financial Reform (conference proceedings). Columbus: Ohio State College of Business.

Life cycle hypothesis. In The New Palgrave Dictionary of Money and Finance, Vol. 2, pp. 580-586. London: Macmillan.

On the wealth of nations. In Michael Fry, ed., Adam Smith's Legacy. London and New York: Routledge. Per capita income and the national saving rate: A life cycle perspective. In Soumitra Sharma, ed., Development Policy, pp. 83-95. New York: St. Martin's Press.

Saving in developing countries: Growth, income, and other factors. In S.G. Rhee and R.P. Chang, eds., Pacific-Basin Capital Markets Research, Vol. 3, pp. 23-35. Amsterdam: Elsevier.

\section{3}

Introduction. In Arnold Heertje, ed., World Savings: An International Survey. Oxford, England, and Cambridge, MA: Blackwell.

Long-term financing in an inflationary environment. Pacific-Basin Finance Journal 1, 99-104.

Los sindicatos son, en buena parte, responsables del paro en España. ABC: Diario de Economía.

1993: L'Anno della grande occasione. In Italia 93: Dalla Tempesta Alla Grande OccasioneEconomica, politica, societa civile: le vie d'uscita, a cura di mario Baldassarri e Franco Modigliani, Monographie RPE-16, Editore SIPI, Sipi.

\section{4}

El desempleo en España: Una propuesta de polótica económica, with Javier de Quinto Romero. Colegio de Economistas 61, 111-116.

The European unemployment crisis: A Monetarist-Keynesian approach and its implications, presented at Institute of Capital Market Research, Johann Wolfgang Goethe Universität, 1994, and published in Wolfgang Gebauer and Bernd Rudolph, eds., Finanzmärkte und Zentralbankpolitik 381, pp. 11-37. Frankfurt: Fritz Knapp Verlag, 1995; Le privatizzazioni: Chiarificazioni e suggerimenti, in Benessere, equilibrio e sviluppo: Studi in onore di Siro Lombardini, Vol. 1. Milan: Vita e Pensiero.

Los sindicatos, responsables de la baja competitividad al exigir desmesurados aumentos salariales. ABC Diario de Economía, 23 January 1994. 


\section{5}

1993: The year of the great opportunity? In Franco Modigliani and Mario Baldassarri, eds., The Italian Economy: What Next?, pp. 97-111. London: Macmillan.

\section{6}

La concertation: Éléments fondamentaux pour un dévelooppement économique et financier qualitatif. L'Europe des partenaires sociaux [The Europe of social partners] from La Conférence Européenne (The European Conference), pp. 140-147.

L'enigma del risparmio cinese e l'ipotesi del ciclo vitale, with Larry Shi Cao, Rivista Italiana Degli Economisti [Italian translation of "The Chinese Saving Puzzle"], pp. 157-184.

The shameful rate of unemployment in the EMS. In De Economist 144, 363-396 [Eighth Jan Timbergen Memorial Lecture, Amsterdam, 1994].

\section{7}

The business expectations and strategy for the United States of Europe, with Hossein Askari. Strategy and Business 70-78.

Riflessioni conclusive. In Globalizzazione Dei Mercati e Orizzonti del Capitalismo, pp. 173-183.

Risk-adjusted performance, with Leah Modigliani. Journal of Portfolio Management 23, 45-54.

The shameful rate of unemployment in the EMS: Causes and cures. In Stefan Collignon, ed., European Monetary Policy, pp. 242-270. London: Pinter Press.

\section{8}

An economists' manifesto on unemployment in the European Union, with J.P. Fitoussi, B. Moro, D. Snower, R. Solow, A. Steinherr, and P. Sylos Labini. Banca Nazionale Del Lavoro Quarterly Review 51, 327-361.

Exchange rate and economic policy in three regional blocks: The EU, The GCC and the CFA, with Hossein Askari. Financial Crisis Management in Regional Blocs, Scheherazade S. Rehman, ed., pp. 115-146. Kluwer Academic.

Lessons learned from Barbara, Feminist Economics 4, 143-144.

Social Security: Una proposta per 1'Italia, with M. Ceprini. Economia Italiana 275-305.

\section{9}

Technologically improved plan administration will enhance retirement savings. Pension Actuary (29)3, 4-5, 16-19. 